\title{
Gastrointestinal stromal tumors: a case-only analysis of single nucleotide polymorphisms and somatic mutations
}

\author{
Katie M O'Brien ${ }^{1}$, Irene Orlow², Cristina R Antonescu ${ }^{3}$, Karla Ballman ${ }^{4}$, Linda McCall ${ }^{5}$, Ronald DeMatteo ${ }^{6}$ \\ and Lawrence S Engel ${ }^{1 *}$
}

\begin{abstract}
Background: Gastrointestinal stromal tumors are rare soft tissue sarcomas that typically develop from mesenchymal cells with acquired gain-in-function mutations in KIT or PDGFRA oncogenes. These somatic mutations have been well-characterized, but little is known about inherited genetic risk factors. Given evidence that certain susceptibility loci and carcinogens are associated with characteristic mutations in other cancers, we hypothesized that these signature KIT or PDGFRA mutations may be similarly fundamental to understanding gastrointestinal stromal tumor etiology. Therefore, we examined associations between 522 single nucleotide polymorphisms and seven KIT or PDGFRA tumor mutations types. Candidate pathways included dioxin response, toxin metabolism, matrix metalloproteinase production, and immune and inflammatory response.
\end{abstract}

Methods: We estimated odds ratios and 95\% confidence intervals for associations between each candidate SNP and tumor mutation type in 279 individuals from a clinical trial of adjuvant imatinib mesylate. We used sequence kernel association tests to look for pathway-level associations.

Results: One variant, rs1716 on ITGAE, was significantly associated with KIT exon 11 non-codon 557-8 deletions (odds ratio $=2.86,95 \%$ confidence interval: 1.71-4.78) after adjustment for multiple comparisons. Other noteworthy associations included rs3024498 (IL10) and rs1050783 (F13A1) with PDGFRA mutations, rs2071888 (TAPBP) with wild type tumors and several matrix metalloproteinase SNPs with KIT exon 11 codon 557-558 deletions. Several pathways were strongly associated with somatic mutations in PDGFRA, including defense response $(p=0.005)$ and negative regulation of immune response $(p=0.01)$.

Conclusions: This exploratory analysis offers novel insights into gastrointestinal stromal tumor etiology and provides a starting point for future studies of genetic and environmental risk factors for the disease.

Keywords: Gastrointestinal stromal tumors, Somatic mutations, Single nucleotide polymorphisms, Epidemiology, Genetics

\section{Background}

Gastrointestinal stromal tumors, or GISTs, are soft tissue sarcomas that develop from mesenchymal connective tissue anywhere in the gastrointestinal tract, though they most frequently appear in the stomach or small intestine [1-3]. Recent advances in molecular biology have revealed a distinct subset of these tumors that express tyrosine

\footnotetext{
* Correspondence: Larry.Engel@unc.edu

${ }^{1}$ Department of Epidemiology, Gillings School of Global Public Health,

University of North Carolina, Chapel Hill, NC, USA

Full list of author information is available at the end of the article
}

kinase receptors or platelet-derived growth factor receptors [4-6]. The presence of these receptors, encoded by the KIT or PDGFRA oncogenes, respectively, is an indication that these tumors share a common origin of the interstitial cells of Cajal, the pacemaker cells of the gut. The Cajal cells normally express both CD117, the immunohistochemical (IHC) marker for tyrosine kinase receptors, and CD34, the IHC marker for platelet-derived growth factor receptors, and GISTs likely develop from

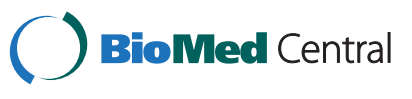

(c) 2013 O'Brien et al.; licensee BioMed Central Ltd. This is an Open Access article distributed under the terms of the Creative Commons Attribution License (http://creativecommons.org/licenses/by/2.0), which permits unrestricted use, distribution, and reproduction in any medium, provided the original work is properly cited. The Creative Commons Public Domain Dedication waiver (http://creativecommons.org/publicdomain/zero/1.0/) applies to the data made available in this article, unless otherwise stated. 
Cajal cells with acquired gain-in-function KIT or PDGFRA mutations $[4,7,8]$. KIT exon 11 (50-60\% of cases) and KIT exon 9 (5-10\% of cases) are the most common mutation sites $[2,9,10]$. Such mutations can enable receptor activation in the absence of normal stem cell factor signaling mechanisms, thereby over-stimulating cell proliferation and leading to tumor development. Based on this discovery, a 2001 National Institutes of Health consensus panel [8] agreed to formally define GISTs as mesenchymal neoplasms of the gastrointestinal tract displaying positivity for CD117 or CD34, with some exceptions allowed for immunonegative tumors with otherwise consistent histology.

These relatively new and complex diagnostic criteria make disease surveillance and etiologic study difficult. In a recent evaluation of patients in the National Cancer Institute's Surveillance, Epidemiology and End Results database, Rubin et al. [11] estimated an annual age-adjusted incidence rate of 0.32 cases per 100,000 individuals in the United States (US). The rarity of the disease makes it a difficult subject for populationbased research or for prompt and unbiased assessment of non-genetic risk factors in any study population. An evaluation of the genetic determinants of GIST is much more feasible, as the germline DNA of individuals does not change over time or in response to disease processes. To date, no other research groups have published such evaluations.

To help fill this knowledge gap, we investigated the genetic determinants of GIST in a case-only analysis. Specifically, we examined the associations between select single nucleotide polymorphisms (SNPs), which are inherited variations in individuals' DNA, and the several common types of acquired KIT and PDGFRA mutations present in GIST tissue. Certain susceptibility loci have been linked to characteristic mutations, or mutational "signatures", in other cancers. These include associations between GSTM1-null genotype and TP53 transversion mutations among bladder cancer patients [12], and certain functional polymorphisms in XPD and $\mathrm{G}: \mathrm{C} \rightarrow \mathrm{T}: \mathrm{A}$ TP53 mutations among lung cancer patients [13]. Similarly, we hypothesized that the characteristic somatic mutations in the KIT and PDGFRA genes in GIST tumors may be mutational signatures that are causally linked to specific mutagens or susceptibility loci. As such, identifying risk factors for the individual tumor subtypes may be fundamental to understanding the disease.

We conducted our evaluation in two phases. The first phase included genes previously linked to soft tissue sarcoma or to environmental risk factors for soft tissue sarcoma, such as dioxins, phenoxyherbicides, insecticides, and vinyl chloride [14-18], as well as genes previously linked to mutational signatures in other cancers $[12,13,19-21]$. We found that several SNPs were associated with GIST tumor subtypes, including SNPs on two xenobiotic metabolizing genes, CYP1B1 and GSTM1, and two DNA repair genes, $R A D 23 B$ and ERCC2 [22].

The present report includes results from the second phase of the study, in which we examined the relationship between these 7 somatic mutation categories and 522 additional candidate SNPs. These SNPs are located on genes that play secondary or less wellunderstood roles in dioxin response or toxin-metabolizing pathways, as well as SNPs on PDGFRA and 10 matrix metalloproteinase $(M M P)$ genes, which are often overexpressed in GISTs and other soft tissue sarcomas and may be linked to tumor invasion and metastasis [23-25]. Based on previous evidence that immune and inflammation-related genes are associated with osteosarcomas and other gastrointestinal tumors [26-28], we also selected certain SNPs from the GeneChip ${ }^{\oplus}$ Human Immune and Inflammation SNP Kit genotyping panel designed by Affymetrix ${ }^{\oplus}[29,30]$.

Our main objective for these analyses was to identify genes or gene pathways potentially related to GIST carcinogenesis. Therefore, in addition to assessing the effect of each individual SNP, we also assessed the joint effects of SNPs in the same functional categories. By conducting these exploratory analyses with a large and diverse gene panel, our goal is to identify specific variants, genes, or functional pathways meriting further investigation.

\section{Methods}

\section{Study population}

The study population consists of the first 279 individuals from the American College of Surgeons Oncology Group (ACOSOG) Z9001 clinical trial who provided blood and tumor tissue samples for ancillary research and had sufficient tumor tissue for mutation analysis. The Z9001 trial was a multicenter, Phase III, randomized, doubleblind study of adjuvant imatinib (Gleevec ${ }^{\mathrm{Ts}}$; Novartis Pharmaceuticals) versus placebo. To be eligible for the clinical trial, cases had to have a $\mathrm{CD} 117+$, resected, localized, primary GIST of at least $3 \mathrm{~cm}$ diagnosed between July 1, 2002 and April 18, 2007. IHC staining for CD117 was completed using the Dako antibody (DakoCytomation, Copenhagen, Denmark). Additional information on the Z9001 trial is published elsewhere [31]. Institutional Review Boards at all participating institutions approved this ancillary study and all of the included participants consented to the use of their blood and tissue specimens.

\section{SNP selection}

Among the target genes described above, we identified SNPs within 2000 or 500 base pairs of the $5^{\prime}$ and 3' ends of the coding regions, respectively, that could affect gene function and had at least a $10 \%$ minor allele 
frequency in the HapMap CEU population [32]. This included nonsense, missense and splice site mutations, as well as SNPs overlapping with microRNA seed regions or transcription binding sites. If the selected SNPs did not meet design phase quality control standards (designability score $<1$ or final score $<0.7$ ), we selected a surrogate SNP in high linkage disequilibrium with the desired SNP. SNPs related to dioxin response or toxin metabolism (final $\mathrm{n}=68$ ), matrix metalloproteinase (final $\mathrm{n}=24$ ), or on PDGFRA (final $\mathrm{n}=4$ ) were selected in this manner.

We selected the remaining SNPs (final $n=426$ ) from a pre-existing Affymetrix ${ }^{\bullet}$ panel designed to include potentially functional non-synonymous SNPs from 318 genes related to immune and inflammatory response. Genes were selected for inclusion based on their gene ontology (GO) categorization [33]. GO categories were also used to separate the genes into functional subgroups (see Additional file 1: Table S1).

\section{Lab assays}

DNA for mutation analysis was extracted from snapfrozen tumor tissue and tested for KIT exon 11 mutations using polymerase chain reaction (PCR) analysis (Platinum TaqDNA Polymerase High Fidelity; Life Technologies, Inc., Gaithersburg, MD). The PCR conditions were as follows: 1) $94^{\circ} \mathrm{C}$ for $4 \mathrm{~min}$; 2) $94^{\circ} \mathrm{C}$ for $30 \mathrm{sec}$, 3) the relevant annealing temperature for each primer set for $30 \mathrm{sec}$, 4) $72^{\circ} \mathrm{C}$ for $30 \mathrm{sec}$ ( 35 cycles); and 5) $72^{\circ} \mathrm{C}$ for $3 \mathrm{~min}$. The PCR products were identified by agarose gel electrophoresis using a 2\% MetaPhor ${ }^{\mathrm{TM}}$ agarose gel (BioWhittaker Applications, Rockland, ME). The PCR products were purified with the QIAquick ${ }^{\text {TM }}$ PCR Purification Kit (Qiagen Inc., Valencia, CA) before sequencing. The sequencing reactions for each case were performed from both the forward and reverse directions. Tumors lacking exon 11 mutations were genotyped for mutations in KIT exons 9, 13, 14 and 17 and PDGFRA exons 12 and 18. A more detailed description of these assays can be found elsewhere [34,35].

An initial 544 candidate SNPs were genotyped using the GoldenGate genotyping assay (Illumina Inc., San Diego, CA). Briefly, allele-specific oligos were hybridized directly to genomic DNA extracted from the blood samples. The hybridized DNA was extended and ligated to downstream locus-specific oligos and then amplified using universal PCR fluorescently labeled primers and allele-specific primers [30,36]. After the resulting products were hybridized to their complementary bead types, the arrays were assessed using the BeadArray $^{\mathrm{TM}}$ Reader.

Twenty-seven participants underwent duplicate genotype analysis for quality assurance purposes. Concordance for duplicate samples was $99.9 \%$. After excluding SNPs that were mono-allelic $(n=3)$, had $>5 \%$ missing data $(\mathrm{n}=3)$, or showed poor clustering $(\mathrm{n}=16)$ among our study subjects, we had 522 evaluable SNPs, as listed above. We retained three SNPs that showed evidence of possible copy number variation, but designated them accordingly.

\section{Statistical analysis}

We conducted descriptive analyses of selected demographic variables, tumor characteristics and genotypes. As this population includes some non-white participants, we calculated race-specific MAFs and compared genotype distributions across racial groups (white vs. other) using a Pearson $\chi^{2}$ test of association. Fisher's exact test was used if one or more cells had less than 5 observations.

We categorized each individual's tumor based on the presence or absence of each of the following outcomes: i) a deletion of KIT exon 11 codons 557-558, ii) any other (i.e. non-codon 557-8) deletion in KIT exon 11, iii) a KIT exon 11 insertion, iv) a KIT exon 11 point mutation, v) a KIT exon 9, exon 13, exon 14, or exon 17 mutation, vi) a PDGFRA exon 12 or 18 mutation, and vii) no KIT or PDGFRA mutation (wild type). KIT mutations in exons $9,13,14$ and 17 were too rare for independent evaluation.

We obtained odds ratios (ORs), 95\% confidence intervals (CIs) and p-values for each SNP-mutation combination using logistic regression. All models were adjusted for race, sex, and age at diagnosis. We assumed additive genetic models, denoting whether an individual had 0,1 or 2 copies of the minor allele. P-values were calculated using trend tests and were corrected for multiple testing by controlling for a false discovery rate of $25 \%$. This method is less conservative than a Bonferroni approach and is thus better suited for a hypothesis-generating study such as this [37].

We used a sequence kernel association test (SKAT) to assess the joint effect of a group of SNPs on an outcome $[38,39]$. We grouped SNPs according to their functional category, as described above. This method is well-powered to detect associations when SNPs in a group are correlated with one another but only moderately associated with the outcome. Briefly, for individual $i$, the log odds of having the outcome given genotypes $z_{\mathrm{i} 1}$ to $z_{\mathrm{ip}}$ and covariates $x_{\mathrm{i} 1}$ to $x_{\mathrm{im}}$ is modeled semiparametrically using a logistic kernel-machine regression model:

$$
\begin{aligned}
\operatorname{logit} \mathrm{P}\left(y_{i}=1\right)= & \alpha_{0}+\alpha_{1} x_{i 1}+\cdots+\alpha_{m} x_{i m} \\
& +h\left(z_{i 1}, z_{i 2}, \ldots, z_{i p}\right),
\end{aligned}
$$


where $h\left(Z_{\mathbf{i}}\right)$ is a function of a positive, definite kernel function, $K(\bullet, \bullet)$ and some $\gamma_{\mathrm{i}}, \ldots, \gamma_{\mathrm{n}}$ :

$$
h\left(Z_{i}\right)=\sum_{i=1}^{n} \gamma_{i^{\prime}} K\left(Z_{i}, Z_{i^{\prime}}\right)
$$

We used an identity-by-state kernel: $K\left(Z_{i}, Z_{i^{\prime}}\right)=$ $\sum_{j=1}^{p}\left(2-\left|Z_{i j}-Z_{i^{\prime} j}\right|\right)$, as this does not require linearity assumptions and allows for epistasis [39]. Assuming $\mathbf{h}$ follows an arbitrary distribution with a mean of 0 and variance $\tau \mathbf{K}$, testing the null hypothesis $\mathrm{H}_{0}: h(\mathbf{Z})=0$ is equivalent to testing $\mathrm{H}_{0}: \tau=0$. This is accomplished using a modified variance-component score statistic:

$$
Q=\frac{\left(y-\hat{p}_{0}\right)^{\prime} K\left(y-\hat{p}_{0}\right)}{2},
$$

where logit

$$
\hat{p}_{0 i}=\hat{a}_{0}+\hat{a}_{1} x_{i 1}+\hat{a}_{2} x_{i 2}+\cdots+\hat{a}_{m} x_{i m} .
$$

Here, $Q$ is comparable to a $\chi^{2}$ distribution with scale parameter $\mathrm{K}$ and $v$ degrees of freedom, both of which are modified to account for correlation between SNPs in the same SNP-set (for calculations, see Appendix A in Wu et al. [38]).

\section{Results}

Males and females were approximately equally represented in our study population, while $18 \%$ were nonwhite (Table 1). Median age at diagnosis was 58 years (range 18-85), though non-white participants tended to be younger (median age $=53$ years). Non-white participants were also more likely to have a smaller tumor than white participants (median tumor sizes of $6.0 \mathrm{~cm}$ versus $6.5 \mathrm{~cm})$, and more likely to have stomach tumors $(74 \%$ versus 64\%). Most patients had mutations in KIT exon 11 (70\% overall), the largest proportion of which were codon 557-558 deletions (34\% of exon 11 mutations). Demographic and tumor characteristics were very similar for males and females.

Compared with the larger ACOSOG Z9001 cohort, whites were somewhat over-represented in this ancillary study, which had otherwise similar characteristics (data not shown). Race-stratified MAF and association p-values for all 522 SNPs are displayed in Additional file 1: Table S2. As expected based on genotype distributions in ethnically diverse HapMap populations [32], genotype distributions in this study differed by race for many of the candidate polymorphisms.

The top 5 SNPs for each mutation subtype are displayed in Table 2. Only one SNP, rs1716 on ITGAE, was statistically significant after adjusting for multiple comparisons. This SNP was associated with KIT exon
11 non-codon $557-8$ deletions $(\mathrm{OR}=2.86,95 \% \mathrm{CI}$ : $1.71,4.78 ; \mathrm{p}=6.4 \times 10^{-5}$ ).

Though not statistically significant after adjusting for multiple comparisons, rs3024498 (IL1O) and rs1050783 (F13A1) were strongly associated with PDGFRA mutations $(\mathrm{OR}=0.31,95 \% \mathrm{CI}$ : 0.16,0.60 and $\mathrm{OR}=0.31,95 \% \mathrm{CI}$ : $0.16,0.61$, respectively) and rs2071888 (TAPBP) was strongly associated with wild type tumors $(\mathrm{OR}=0.37,95 \% \mathrm{CI}: 0.20$, 0.67). Additionally, several SNPs in matrix metalloproteinase genes were associated with tumor subtypes. MMP10 and MMP1 SNPs were associated with KIT exon 11 codon 557-558 deletions, 2 MMP7 SNPs were associated with $K I T$ exon 11 point mutations and a MMP1 SNP was associated with KIT exon 9, 13, 14, or 17 mutations. Effect estimates and p-values for all 522 SNPs can be found in Additional file 1: Table S3. The relative magnitude of all SNP-subtype associations is depicted in Figure 1.

Despite strong SNP-level effects, the $M M P$ pathway was not associated with any of the tumor subtypes in the SKAT analyses (minimum p-value $=0.2$ for KIT exon 11 point mutations; Additional file 1: Table S4). As seen in Table 3, the strongest pathway-level associations were in relation to somatic mutations in PDGFRA. This included defense response $(\mathrm{p}=0.005)$, negative regulation of immune response $(\mathrm{p}=0.01)$, protein phosphorylation $(p=0.02)$, positive regulation of immune response $(\mathrm{p}=0.03)$, and AHR/dioxin response (0.03). Additionally, negative regulation of cell proliferation was associated with PDGFRA mutations $(\mathrm{p}=0.04$; Additional file 1 : Table S4). In total, only 5 other pathways were associated with a tumor subtype at $\mathrm{p}<0.05$. These were AHR/dioxin response with non exon 11 KIT mutations $(\mathrm{p}=0.01)$, humoral immune response with wild type mutations $(\mathrm{p}=0.02)$, and response to stress, negative regulation of apoptosis, and protein tyrosine kinase activity with non-codon 557-8 KIT exon 11 deletions $(\mathrm{p}=0.02, \mathrm{p}=0.03$, and $\mathrm{p}=0.04$, respectively). No pathways were statistically significant after correcting for multiple testing. Log p-values for all pathway analyses can be seen in Figure 2.

\section{Discussion}

In this exploratory analysis of genetic risk factors for GIST tumor subtypes, we identified one statistically significant association and a number of other potentially important associations for individual polymorphisms. We also identified several potentially relevant functional pathways. These novel findings offer clues about the etiology of these rare and poorly understood tumors.

The SNP with the strongest association with a tumor subtype was rs1716 on ITGAE. This SNP results in a missense mutation on ITGAE (also known as CD103), a gene involved in protein tyrosine phosphatase activity. 
Table 1 Demographic information and tumor characteristics of patients included in genotyping ancillary study

\begin{tabular}{|c|c|c|c|c|c|}
\hline & \multirow{2}{*}{$\frac{\text { Overall sample }}{\mathrm{N}=\mathbf{2 7 9}}$} & \multicolumn{2}{|c|}{ Sex stratified } & \multicolumn{2}{|c|}{ Race stratified } \\
\hline & & $\begin{array}{c}\text { Male } \\
(n=142)\end{array}$ & $\begin{array}{l}\text { Female } \\
(n=137)\end{array}$ & $\begin{array}{c}\text { White } \\
(n=229)\end{array}$ & $\begin{array}{c}\text { Other } \\
(n=50)\end{array}$ \\
\hline Age: Median (range) & $58.0(18-85)$ & $57.0(18-85)$ & $58.0(18-81)$ & $59.0(18-85)$ & $53.0(27-78$ \\
\hline
\end{tabular}

Sex: $\mathbf{N}(\%)$

$\begin{array}{rr}\text { Male } & 142(51) \\ \text { Female } & 137(49)\end{array}$

Race: N (\%)

\begin{tabular}{|c|c|c|c|c|c|}
\hline White & $229(82)$ & $122(86)$ & 107 (78) & - & - \\
\hline Other & $50(18)$ & $20(14)$ & $30(22)$ & - & - \\
\hline nge) & $6.5(3.0-37.0)$ & $6.0(3.0-37.0)$ & $6.5(3.0-28.0)$ & $6.5(3.0-37.0)$ & $6.0(3.1-30.0)$ \\
\hline
\end{tabular}

Tumor Size: Median (range)

Tumor Size: N(\%)

$\begin{array}{rr}<5 \mathrm{~cm} & 79(28) \\ 5-10 \mathrm{~cm} & 146(52) \\ >10 \mathrm{~cm} & 54(19)\end{array}$

Mitotic Rate: Median (range)

Mitotic Rate: N(\%)

$\begin{array}{rc}<5 & 156(60) \\ \geq 5 & 104(40) \\ \text { Missing } & 19\end{array}$

Tumor Location: N(\%)

Stomach
Small Intestine
Rectum
Other
Missing

Mutation Type: N(\%)

Exon 9
Exon 11
Exon 13
Exon 14
Exon 17
PDGFRA
Wild type

Exon 11 mutation type: N(\%)

$$
\begin{array}{r}
\text { 557-558 deletion } \\
\text { Other deletion } \\
\text { Insertion } \\
\text { Point Mutation }
\end{array}
$$

PDGFRA mutation type: N(\%)

D842V

Other

$$
\begin{gathered}
182(66) \\
85(31) \\
2(1) \\
8(3) \\
2
\end{gathered}
$$

$$
\begin{gathered}
15(5) \\
195(70) \\
3(1) \\
1(0) \\
0(0) \\
29(10) \\
36(13)
\end{gathered}
$$

$$
66 \text { (34) }
$$$$
45 \text { (23) }
$$$$
28 \text { (14) }
$$$$
56 \text { (29) }
$$

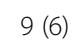

$95(67)$

0 (0)

$1(1)$

$0(0)$

$21(15)$

16 (11)

33 (35)

25 (26)

14 (15)

23 (24)

$$
12 \text { (41) }
$$$$
17 \text { (59) }
$$

10 (48)

11 (52)

$$
\begin{gathered}
38(28) \\
74(54) \\
25(18) \\
3(0-207)
\end{gathered}
$$

$79(63)$
$47(37)$
11

85 (63)

46 (34)

$1(1)$

4 (3)

$$
1
$$

\section{6 (4)}

$100(73)$

3 (2)

0 (0)

$0(0)$

8 (6)

20 (15)

$33(33)$
$20(20)$
$14(14)$
$33(33)$

33 (33)

14 (14)

33 (33)

2 (25)

$6(75)$

$$
\begin{gathered}
65(28) \\
119(52) \\
45(20) \\
3(0-351)
\end{gathered}
$$$$
14 \text { (28) }
$$$$
27 \text { (54) }
$$$$
9 \text { (18) }
$$$$
4.5(0-81)
$$

$\begin{array}{cc}132(62) & 24(50) \\ 80(38) & 24(50) \\ 17 & 2\end{array}$

$\begin{array}{cc}146(64) & 36(74) \\ 77(34) & 8(16) \\ 1(0) & 1(2) \\ 4(2) & 4(8) \\ 1 & 1 \\ 15(7) & 0(0) \\ 153(67) & 42(84) \\ 2(1) & 1(2) \\ 1(0) & 0(0) \\ 0(0) & 0(0) \\ 25(11) & 4(8) \\ 33(14) & 3(6)\end{array}$

$\begin{array}{lc}51(33) & 15(36) \\ 34(22) & 11(26) \\ 23(15) & 5(12) \\ 45(29) & 11(26)\end{array}$

10 (40)

2 (50)

15 (60) 
Table 2 Odds ratios (ORs) for top 5 SNP-mutation associations, by mutation type

\begin{tabular}{|c|c|c|c|c|c|c|}
\hline & Gene & MMP10 & MMP1 & MMP10 & SELP & GRN \\
\hline & SNP & rs3819099 & rs17293642 & rs17293348 & rs6131 & rs5848 \\
\hline \multirow[t]{5}{*}{ KIT exon 11 codon $557-558$ deletion } & $\mathrm{MAF}^{\mathrm{a}}$ & $0.11 / 0.20$ & $0.11 / 0.20$ & $0.12 / 0.20$ & $0.18 / 0.30$ & $0.31 / 0.45$ \\
\hline & OR $(95 \% \mathrm{Cl})$ & $2.29(1.30,4.01)$ & $2.17(1.25,3.77)$ & $2.16(1.24,3.77)$ & $1.81(1.18,2.78)$ & $1.78(1.17,2.73)$ \\
\hline & p-value & 0.004 & 0.006 & 0.007 & 0.007 & 0.007 \\
\hline & Gene & ITGAE & CDK2 & FCER1G & ZAP70 & LIF \\
\hline & SNP & rs1716 & rs2069398 & rs11421 & rs2276645 & rs737812 \\
\hline \multirow[t]{5}{*}{ KIT exon 11 other (non-codon 557-8) deletion } & $\mathrm{MAF}^{\mathrm{a}}$ & $0.25 / 0.45$ & $0.07 / 0.19$ & $0.15 / 0.27$ & $0.40 / 0.22$ & $0.35 / 0.20$ \\
\hline & OR $(95 \% \mathrm{Cl})$ & $2.86(1.71,4.78)$ & $2.62(1.34,5.13)$ & $2.13(1.24,3.64)$ & $0.49(0.28,0.83)$ & $0.47(0.26,0.83)$ \\
\hline & p-value & 0.00006 & 0.005 & 0.006 & 0.008 & 0.01 \\
\hline & Gene & $\mathrm{SH} 2 \mathrm{~B} 3$ & CLCF1 & GZMB & IFI16 & GMIP \\
\hline & SNP & rs3184504 & rs17608 & rs8192917 & rs866484 & rs880090 \\
\hline \multirow[t]{5}{*}{ KIT exon 11 insertion } & $\mathrm{MAF}^{\mathrm{a}}$ & $0.43 / 0.23$ & $0.32 / 0.48$ & $0.24 / 0.41$ & $0.26 / 0.44$ & $0.32 / 0.48$ \\
\hline & OR $(95 \% \mathrm{Cl})$ & $0.31(0.15,0.64)$ & $2.55(1.38,4.72)$ & $2.33(1.28,4.24)$ & $2.36(1.27,4.40)$ & $2.20(1.23,3.94)$ \\
\hline & p-value & 0.002 & 0.003 & 0.006 & 0.007 & 0.008 \\
\hline & Gene & MMP7 & PTGER3 & PTPN12 & MMP7 & SLAMF1 \\
\hline & SNP & rs10502001 & rs959 & rs3750050 & rs14983 & rs2295612 \\
\hline \multirow[t]{5}{*}{ KIT exon 11 point mutation } & $\mathrm{MAF}^{\mathrm{a}}$ & $0.18 / 0.29$ & $0.18 / 0.31$ & $0.16 / 0.29$ & $0.19 / 0.29$ & $0.17 / 0.07$ \\
\hline & OR $(95 \% \mathrm{Cl})$ & $2.20(1.32,3.66)$ & $1.99(1.25,3.17)$ & $2.01(1.25,3.25)$ & $2.03(1.22,3.39)$ & $0.33(0.15,0.74)$ \\
\hline & $p$-value & 0.003 & 0.004 & 0.004 & 0.006 & 0.007 \\
\hline & Gene & LILRA4 & LAG3 & IL4R & MMP1 & ITGAE \\
\hline & SNP & rs2241384 & rs870849 & rs1805015 & rs4754880 & rs1716 \\
\hline \multirow[t]{5}{*}{ Other KIT mutation } & $\mathrm{MAF}^{\mathrm{a}}$ & $0.17 / 0.36$ & $0.36 / 0.42$ & $0.18 / 0.36$ & $0.18 / 0.36$ & $0.27 / 0.50$ \\
\hline & OR $(95 \% \mathrm{Cl})$ & $2.89(1.36,6.16)$ & $2.76(1.33,5.74)$ & $2.75(1.32,5.75)$ & $2.49(1.22,5.09)$ & $2.46(1.22,4.99)$ \\
\hline & $p$-value & 0.006 & 0.007 & 0.007 & 0.01 & 0.01 \\
\hline & Gene & IL10 & F13A1 & PLAU & PECAM1 & SPINK5 \\
\hline & SNP & rs3024498 & rs1050783 & rs4065 & rs1050382 & rs6892205 \\
\hline \multirow[t]{5}{*}{ PDGFRA mutation } & $\mathrm{MAF}^{\mathrm{a}}$ & $0.21 / 0.41$ & $0.14 / 0.33$ & $0.46 / 0.24$ & $0.47 / 0.31$ & $0.49 / 0.31$ \\
\hline & OR $(95 \% \mathrm{Cl})$ & $0.31(0.16,0.60)$ & $0.31(0.16,0.61)$ & $2.65(1.37,5.13)$ & $0.43(0.24,0.78)$ & $2.31(1.26,4.24)$ \\
\hline & $p$-value & 0.0004 & 0.0007 & 0.004 & 0.006 & 0.007 \\
\hline & Gene & TAPBP & ESR1 & NCF2 & STAT2 & FGA \\
\hline & SNP & rs2071888 & rs6557171 & rs2274064 & rs2066807 & rs6050 \\
\hline \multirow[t]{3}{*}{ Wild type } & $\mathrm{MAF}^{\mathrm{a}}$ & $0.48 / 0.29$ & $0.38 / 0.46$ & $0.43 / 0.38$ & $0.06 / 0.15$ & $0.26 / 0.39$ \\
\hline & OR $(95 \% \mathrm{Cl})$ & $0.37(0.20,0.67)$ & $2.26(1.35,3.79)$ & $2.35(1.34,4.13)$ & $3.00(1.32,6.83)$ & $2.02(1.19,3.44)$ \\
\hline & $p$-value & 0.001 & 0.002 & 0.003 & 0.009 & 0.009 \\
\hline
\end{tabular}

${ }^{\mathrm{a}}$ Minor allele frequency (MAF) among those without mutation / MAF among those with mutation.

This SNP was previously associated with increased risk of melanoma [40], as was another SNP in the gene. The CD103 protein is commonly expressed in intraepithelial lymphocytic T cells and hairy cell leukemia cells [41,42].

The IL10 SNP associated with PDGFRA mutations, rs3024498, is located in a seed microRNA region. One previous study found an association between rs3024498 and colorectal cancer [43]. The IL10 gene encodes a cytokine that plays a role in immunoregulation and inflammation, and has been previously linked to several cancers, including osteosarcoma [26], cervical cancer [44], and gastric cancer $[45,46]$.

rs1050783 in F13A1 is also in a seed microRNA region, but neither the SNP nor the gene has been previously linked to cancer. The same is true for rs2071888 in TAPBP, a missense mutation. As noted above, several studies have observed over-expression of matrix metalloproteinase genes in GISTs and other soft tissue sarcomas [23-25], though none of the evaluated SNPs have previously been associated with cancer risk. 


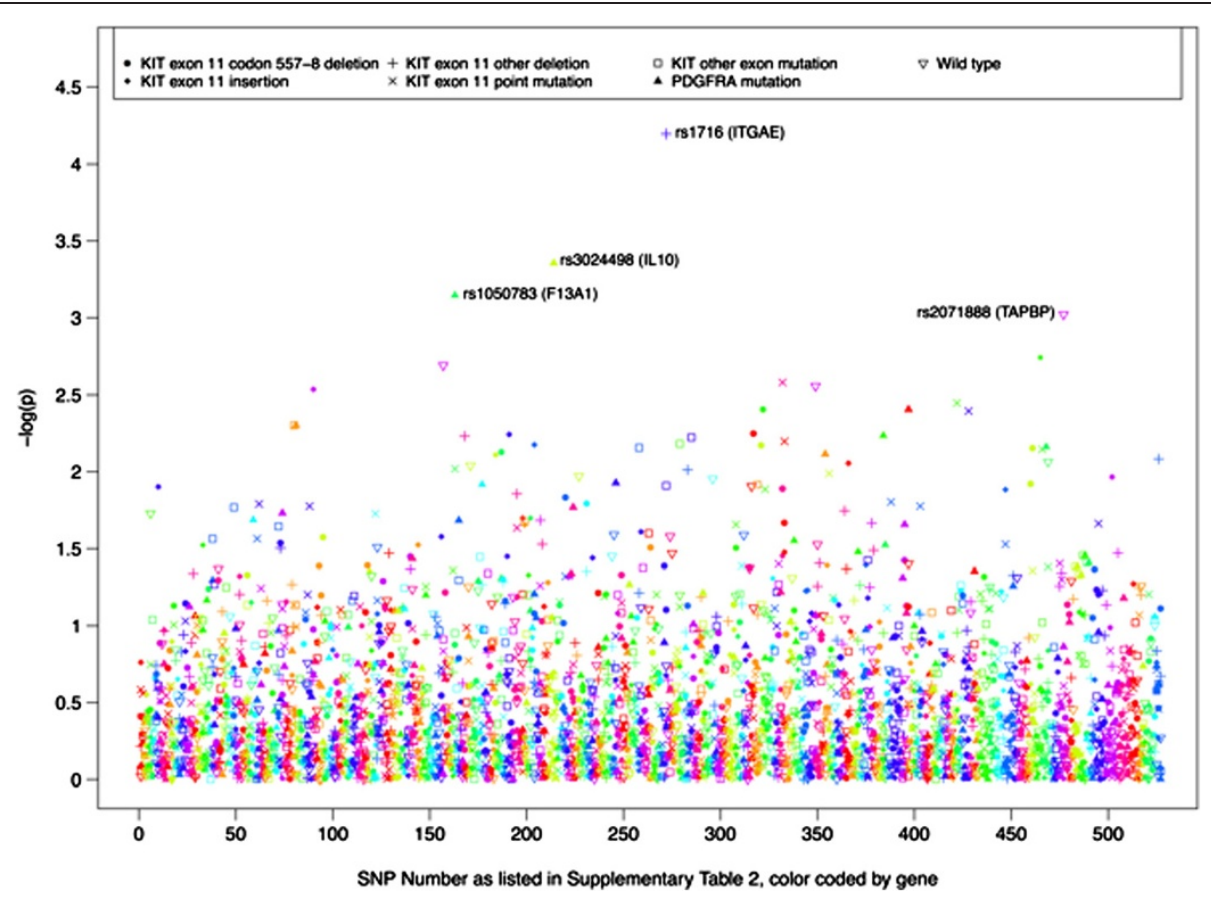

Figure 1 Log p-values for the association between each candidate SNP and tumor mutation type.

Table 3 SKAT p-values for top 5 functional pathway- mutation associations, by mutation type

\begin{tabular}{|c|c|c|c|c|c|c|}
\hline \multirow[t]{2}{*}{$\begin{array}{l}\text { KIT exon } 11 \text { codon } \\
557-558 \text { deletion }\end{array}$} & Pathway & $\begin{array}{l}\text { Negative } \\
\text { regulation of cell } \\
\text { proliferation }\end{array}$ & $\begin{array}{l}\text { Intracellular signal } \\
\text { transduction }\end{array}$ & $\begin{array}{l}\text { Protein tyrosine kinase } \\
\text { phosphatase activity }\end{array}$ & $\begin{array}{l}\text { Humoral immune } \\
\text { response }\end{array}$ & $\begin{array}{l}\text { Cytokine } \\
\text { mediated } \\
\text { signaling } \\
\text { pathway }\end{array}$ \\
\hline & p-value & 0.09 & 0.10 & 0.11 & 0.13 & 0.13 \\
\hline \multirow{2}{*}{$\begin{array}{l}\text { KIT exon } 11 \text { other } \\
\text { (non-codon 557-8) } \\
\text { deletion }\end{array}$} & Pathway & Response to stress & $\begin{array}{l}\text { Negative regulation } \\
\text { of apoptosis }\end{array}$ & $\begin{array}{c}\text { Protein tyrosine kinase } \\
\text { activity }\end{array}$ & $\begin{array}{l}\text { Response to } \\
\text { Hypoxia }\end{array}$ & $\begin{array}{l}\text { T cell receptor } \\
\text { signaling } \\
\text { pathway }\end{array}$ \\
\hline & p-value & 0.02 & 0.03 & 0.04 & 0.06 & 0.08 \\
\hline \multirow[t]{2}{*}{ KIT exon 11 insertion } & Pathway & $\begin{array}{l}\text { Positive regulation } \\
\text { of immune } \\
\text { response }\end{array}$ & Cytochrome P450 & Humoral immune response & Signal transduction & $\begin{array}{c}\text { Signal transduce } \\
\text { activity }\end{array}$ \\
\hline & p-value & 0.10 & 0.11 & 0.17 & 0.17 & 0.20 \\
\hline \multirow{2}{*}{$\begin{array}{l}\text { KIT exon } 11 \text { point } \\
\text { mutation }\end{array}$} & Pathway & $\begin{array}{c}\text { T cell receptor } \\
\text { signaling pathway }\end{array}$ & Immune response & $\begin{array}{c}\text { Positive regulation of cell } \\
\text { proliferation }\end{array}$ & $\begin{array}{l}\text { Intracellular signal } \\
\text { transduction }\end{array}$ & $\begin{array}{l}\text { Phase } 1 / \| \\
\text { metabolizing }\end{array}$ \\
\hline & p-value & 0.06 & 0.18 & 0.19 & 0.20 & 0.20 \\
\hline \multirow[t]{2}{*}{ Other KIT mutation } & Pathway & $\begin{array}{l}\text { AHR/dioxin } \\
\text { response }\end{array}$ & $\begin{array}{l}\text { G-protein coupled } \\
\text { receptor signaling } \\
\text { pathway }\end{array}$ & Protein phosphorylation & $\begin{array}{c}\text { Negative } \\
\text { regulation of } \\
\text { immune response }\end{array}$ & $\begin{array}{l}\text { Cytochrome } \\
\text { P450 }\end{array}$ \\
\hline & p-value & 0.01 & 0.06 & 0.08 & 0.08 & 0.09 \\
\hline \multirow[t]{2}{*}{ PDGFRA mutation } & Pathway & Defense Response & $\begin{array}{l}\text { Negative regulation } \\
\text { of immune response }\end{array}$ & Protein phosphorylation & $\begin{array}{l}\text { Positive regulation } \\
\text { of immune } \\
\text { response }\end{array}$ & $\begin{array}{l}\text { AHR/dioxin } \\
\text { response }\end{array}$ \\
\hline & p-value & 0.005 & 0.01 & 0.02 & 0.03 & 0.03 \\
\hline \multirow[t]{2}{*}{ Wild type } & Pathway & $\begin{array}{l}\text { Humoral immune } \\
\text { response }\end{array}$ & $\begin{array}{c}\text { Defense response to } \\
\text { bacteria }\end{array}$ & $\begin{array}{c}\text { Transmembrane receptor } \\
\text { protein tyrosine phosphatase } \\
\text { activity }\end{array}$ & $\begin{array}{c}\text { Cytokine receptor } \\
\text { activity }\end{array}$ & $\begin{array}{l}\text { Response to } \\
\text { oxidative stress }\end{array}$ \\
\hline & $p$-value & 0.02 & 0.11 & 0.13 & 0.14 & 0.14 \\
\hline
\end{tabular}




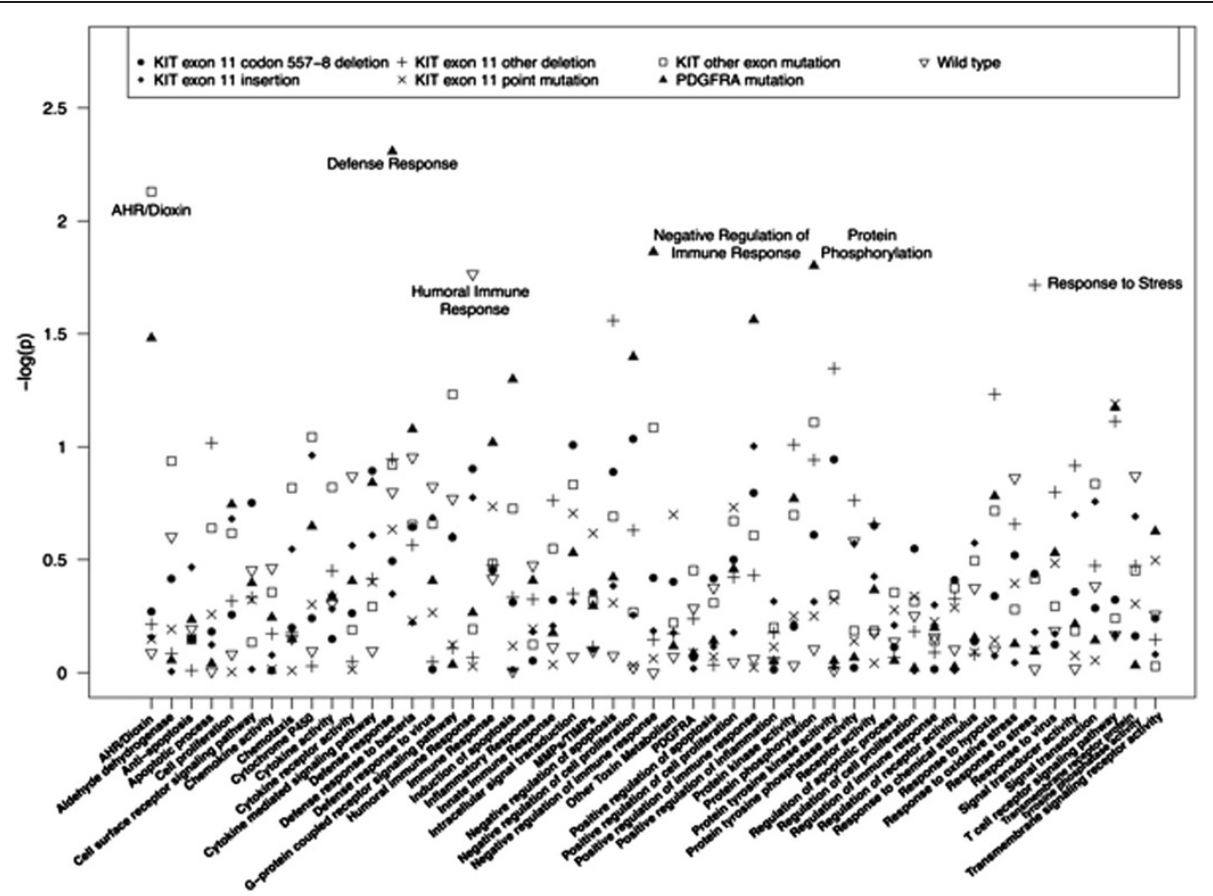

Figure 2 SKAT $\log$ p-values for the association between each functional pathway and tumor mutation type.

Pathway analyses are common in cancer epidemiology, but there is little consistency in how the pathways are defined. We selected the well-documented and publicly available Gene Ontology [33] classification system to facilitate replication and follow-up studies. Although we did not identify any studies that examined the specific pathways included in the present analyses, numerous studies have observed associations of inflammatory or immune response genes with risk of sarcomas or gastrointestinal cancers $[26,28,30,47]$.

The present exploratory study was undertaken in light of evidence suggesting that some mutagens and susceptibility loci are associated with specific mutational "signatures," i.e., characteristic mutation patterns [12,13,19-21]. At this point, GIST etiology has been insufficiently researched, and we do not know how well the mutationbased tumor classifications used in this study correspond to distinct carcinogenic processes. However, the existence of multiple types of mutations suggest that more than one mutagenic process could be involved, and we believe that identifying associations between germline genetic polymorphisms and unique tumor phenotypes could contribute valuable new information about disease etiology. This information could also help to elucidate environmental risk factors for this disease.

Because tumors with KIT exon 11 mutations were not assessed for other KIT or PDGFRA mutations, some tumors may be misclassified, though evidence from population-based studies suggests that few GISTs have more than one mutation type [2,9]. Our study participants had similar mutation profiles to the individuals included in these population-based investigations, but the results from this predominately white clinical trials population may not be generalizable to all GIST patients. Lastly, this study had a small sample size. As such, we had limited power to detect true associations, particularly when the evaluated genotype and mutation type were rare.

\section{Conclusions}

In this novel study of genetic risk factors for GIST, we identified several SNPs and gene pathways associated with GIST mutation subtypes. This included SNPs involved in dioxin response, toxin metabolism, matrix metalloproteinase synthesis, and inflammatory or immune response. While only a single SNP was statistically significant after correcting for multiple comparisons, our overall findings provide an important starting point for future studies of genetic and environmental risk factors for this rare and poorly understood disease.

\section{Additional file}

Additional file 1: Table S1. Genes and gene pathways. Table S2.

Minor allele frequencies (MAF) and p-values for comparison of genotype frequencies: 29001 genotyped whites $(n=273)$ versus non-whites $(n=58)$. Table S3. Odds Ratios (ORs), 95\% Confidence Intervals (Cis) and p-values for the association between candidate SNPs and tumor mutation status in 279 GIST patients. Table S4. P-values for sequence kernel association tests (SKAT) of functional pathways and tumor mutation status. 


\section{Abbreviations}

GISTs: Gastrointestinal stromal tumors; SNPs: Single nucleotide polymorphisms; SKAT: Sequence kernel association test; OR: Odds ratio; Cl: Confidence interval; US: United States; ACOSOG: American college of surgeons oncology group; GO: Gene ontology; PCR: Polymerase chain reaction; MAF: Minor allele frequency.

\section{Competing interests}

This work was supported by Novartis Pharmaceuticals Corp. agreement \#CST1571BUS249. RD previously served as a paid consultant to Novartis Pharmaceuticals. All other authors declare that they have no conflict of interest.

\section{Authors' contributions}

LSE, IO, CRA and RD conceived the study design, selected the candidate genes, and supervised genetic analyses. KMO and LSE designed the statistical analysis and drafted the manuscript. KMO and LM preformed the statistical analyses, with contributions from LSE and KB. All authors read and approved the final manuscript.

\section{Acknowledgements}

We thank Aliaksandra Samoila and Kenneth Cheung for their technical assistance during the preparation of DNA specimens for genotyping and direct sequencing. The authors also wish to thank Michael Wu for his statistical advice. Novartis Pharmaceuticals Corporation provided funding for this research project with agreement \#CSTI571BUS249.

\section{Author details}

${ }^{1}$ Department of Epidemiology, Gillings School of Global Public Health, University of North Carolina, Chapel Hill, NC, USA. ${ }^{2}$ Department of Epidemiology and Biostatistics, Memorial Sloan-Kettering Cancer Center, New York, USA. ${ }^{3}$ Department of Pathology, Memorial Sloan-Kettering Cancer Center, New York, NY, USA. ${ }^{4}$ Department of Health Sciences Research, Mayo Clinic, Rochester, MN, USA. ${ }^{5}$ American College of Surgeons Oncology Group, Durham, NC, USA. ${ }^{6}$ Department of Surgery, Memorial Sloan-Kettering Cancer Center, New York, NY, USA

\section{Received: 18 September 2013 Accepted: 23 October 2013}

Published: 26 October 2013

\section{References}

1. Gastrointestinal stromal tumors treatment $\left(P D Q^{\circledR}\right)$ - national cancer institute. http://www.cancer.gov/cancertopics/pdq/treatment/gist/HealthProfessional.

2. Mazzola P, Spitale A, Banfi S, Mazzucchelli L, Frattini M, Bordoni A: Epidemiology and molecular biology of gastrointestinal stromal tumors (GISTs): a population-based study in the South of Switzerland, 1999-2005. Histol Histopathol 2008, 23:1379-1386.

3. Miranda C, Nucifora M, Molinari F, Conca E, Anania MC, Bordoni A, Saletti P Mazzucchelli L, Pilotti S, Pierotti MA, Tamborini E, Greco A, Frattini M: KRAS and BRAF mutations predict primary resistance to imatinib in gastrointestinal stromal tumors. Clin Cancer Res 2012, 18:1769-1776.

4. Hirota S, Isozaki K, Moriyama Y, Hashimoto K, Nishida T, Ishiguro S, Kawano K, Hanada M, Kurata A, Takeda M, Tunio GM, Matsuzawa Y, Kanakura Y, Shinomura Y, Kitamura Y: Gain-of-function mutations of c-kit in human gastrointestinal stromal tumors. Science 1998, 279:577-580.

5. Nilsson B, Bümming P, Meis-Kindblom JM, Odén A, Dortok A, Gustavsson B, Sablinska K, Kindblom LG: Gastrointestinal stromal tumors: the incidence, prevalence, clinical course, and prognostication in the preimatinib mesylate era-a population-based study in western Sweden. Cancer 2005, 103:821-829.

6. Yan BM, Kaplan GG, Urbanski S, Nash CL, Beck PL: Epidemiology of gastrointestinal stromal tumors in a defined Canadian health region: a population-based study. Int J Surg Pathol 2008, 16:241-250.

7. Rubin BP, Heinrich MC, Corless CL: Gastrointestinal stromal tumour. Lancet 2007, 369:1731-1741.

8. Berman J, O'Leary TJ: Gastrointestinal stromal tumor workshop. Hum Pathol 2001, 32:578-582.

9. Cassier PA, Ducimetière F, Lurkin A, Ranchère-Vince $D$, Scoazec J, Bringuier $P$, Decouvelaere AV, Méeus P, Cellier D, Blay JY, Ray-Coquard I: A prospective epidemiological study of new incident GISTs during two consecutive years in Rhône alpes region: incidence and molecular distribution of GIST in a European region. Br J Cancer 2010, 103:165-170.
10. Steigen SE, Eide TJ: Trends in incidence and survival of mesenchymal neoplasm of the digestive tract within a defined population of northern Norway. APMIS 2006, 114:192-200.

11. Rubin JL, Sanon M, Taylor DC, Coombs J, Bollu V, Sirulnik L: Epidemiology, survival, and costs of localized gastrointestinal stromal tumors. Int J Gen Med 2011, 4:121-130.

12. Ryk C, Berggren $P$, Kumar R, Hemminki K, Larsson P, Steineck $G$, Lambert $B$, Hou SM: Influence of GSTM1, GSTT1, GSTP1 and NAT2 genotypes on the p53 mutational spectrum in bladder tumours. Int J Cancer 2005, 113:761-768.

13. Mechanic LE, Marrogi AJ, Welsh JA, Bowman ED, Khan MA, Enewold L, Zheng YL, Chanock S, Shields PG, Harris CC: Polymorphisms in XPD and TP53 and mutation in human lung cancer. Carcinogenesis 2005, 26:597-604.

14. Kogevinas $M$, Becher $H$, Benn T, Bertazzi PA, Boffetta P, Bueno-de-Mesquita HB, Coggon D, Colin D, Flesch-Janys D, Fingerhut M, Green L, Kauppinen T, Littorin M, Lynge E, Matthews JD, Neuberger M, Pearce N, Saracci R: Cancer mortality in workers exposed to phenoxy herbicides, chlorophenols, and dioxins: an expanded and updated international cohort study. Am J Epidemiol 1997, 145:1061-1075.

15. Boffetta P, Matisane L, Mundt KA, Dell LD: Meta-analysis of studies of occupational exposure to vinyl chloride in relation to cancer mortality. Scand J Work Environ Health 2003, 29:220-229.

16. Hardell L: Pesticides, soft-tissue sarcoma and non-hodgkin lymphomahistorical aspects on the precautionary principle in cancer prevention. Acta Oncol 2008, 47:347-354.

17. Pahwa P, Karunanayake CP, Dosman JA, Spinelli JJ, McLaughlin JR, Cross-Canada Group: Soft-tissue sarcoma and pesticides exposure in men: results of a Canadian case-control study. J Occup Environ Med 2011, 53:1279-1286.

18. Brady MS, Gaynor JJ, Brennan MF: Radiation-associated sarcoma of bone and soft tissue. Arch Surg 1992, 127:1379-1385.

19. Pfeifer GP, Denissenko MF: Formation and repair of DNA lesions in the p53 gene: relation to cancer mutations? Environ Mol Mutagen 1998, 31:197-205.

20. Olivier M, Hussain SP, Caron De Fromentel C, Hainaut P, Harris CC: TP53 mutation spectra and load: a tool for generating hypotheses on the etiology of cancer. IARC Sci Publ 2004, 157:247-270.

21. Dixon K, Kopras E: Genetic alterations and DNA repair in human carcinogenesis. Semin Cancer Biol 2004, 14:441-448.

22. O'Brien KM, Orlow I, Antonescu CR, Ballman KV, McCall L, DeMatteo RP, Engel LS: Gastrointestinal stromal tumors, somatic mutations and candidate genetic risk variants. PLoS One 2013, 8:e62119.

23. Alford SH, Vrana MS, Waite L, Heim-Hall J, Sylvia VL, Williams RP: Matrix metalloproteinase expression in high grade soft tissue sarcomas. Oncol Rep 2007, 18:1529-1536.

24. Nabeshima K, Iwasaki H, Nishio J, Koga K, Shishime M, Kikuchi M: Expression of emmprin and matrix metalloproteinases (MMPs) in peripheral nerve sheath tumors: emmprin and membrane-type (MT)1-MMP expressions are associated with malignant potential. Anticancer Res 2006, 26:1359-1367.

25. Nakagawa M, Nabeshima K, Asano S, Hamasaki M, Uesugi N, Tani H, Yamashita $Y$, Iwasaki $\mathrm{H}$ : Up-regulated expression of ADAM17 in gastrointestinal stromal tumors: coexpression with EGFR and EGFR ligands. Cancer Sci 2009, 100:654-662.

26. Oliveira ID, Petrilli AS, Tavela MH, Zago MA, de Toledo SRC: TNF-alpha, TNF-beta, IL-6, IL-10, PECAM-1 and the MPO inflammatory gene polymorphisms in osteosarcoma. J Pediatr Hematol Oncol 2007, 29:293-297.

27. Walczak A, Przybylowska K, Dziki L, Sygut A, Chojnacki C, Chojnacki J, Dziki A, Majsterek I: The IL-8 and IL-13 gene polymorphisms in inflammatory bowel disease and colorectal cancer. DNA Cell Biol 2012, 31:1431-1438.

28. Hussain SK, Mu L, Cai L, Chang S, Park SL, Oh SS, Wang Y, Goldstein BY, Ding BG, Jiang Q, Rao J, You NCY, Yu SZ, Papp JC, Zhao JK, Wang H, Zhang ZF: Genetic variation in immune regulation and DNA repair pathways and stomach cancer in China. Cancer Epidemiol Biomarkers Prev 2009, 18:2304-2309.

29. Affymetrix ${ }^{\circledR}$ GeneChip ${ }^{\circledR}$ Human Immune and Inflammation 9K SNP Kit: http://media.affymetrix.com/support/technical/datasheets/humanimmune_ 9k_snp datasheet.pdf.

30. Cerhan JR, Ansell SM, Fredericksen ZS, Kay NE, Liebow M, Call TG, Dogan A, Cunningham JM, Wang AH, Liu-Mares W, Macon WR, Jelinek D, Witzig TE, Habermann TM, Slager SL: Genetic variation in 1253 immune and inflammation genes and risk of non-hodgkin lymphoma. Blood 2007, 110:4455-4463. 
31. Dematteo RP, Ballman KV, Antonescu CR, Maki RG, Pisters PWT, Demetri GD, Blackstein ME, Blanke CD, von Mehren M, Brennan MF, Patel S, McCarter MD, Polikoff JA, Tan BR, Owzar K: Adjuvant imatinib mesylate after resection of localised, primary gastrointestinal stromal tumour: a randomised, double-blind, placebo-controlled trial. Lancet 2009, 373:1097-1104.

32. HapMap homepage. http://hapmap.ncbi.nlm.nih.gov/.

33. The gene ontology. http://www.geneontology.org/.

34. Antonescu CR, Sommer G, Sarran L, Tschernyavsky SJ, Riedel E, Woodruff JM, Robson M, Maki R, Brennan MF, Ladanyi M, DeMatteo RP, Besmer P: Association of KIT exon 9 mutations with nongastric primary site and aggressive behavior: KIT mutation analysis and clinical correlates of 120 gastrointestinal stromal tumors. Clin Cancer Res 2003, 9:3329-3337.

35. Dematteo RP, Gold JS, Saran L, Gönen M, Liau KH, Maki RG, Singer S, Besmer P, Brennan MF, Antonescu CR: Tumor mitotic rate, size, and location independently predict recurrence after resection of primary gastrointestinal stromal tumor (GIST). Cancer 2008, 112:608-615.

36. Shen R, Fan J, Campbell D, Chang W, Chen J, Doucet D, Yeakley J, Bibikova M, Garcia EW, McBride C, Steemers F, Garcia F, Kermani BG, Gunderson K, Oliphant A: High-throughput SNP genotyping on universal bead arrays. Mutat Res 2005, 573:70-82.

37. Benjamini $Y$, Drai D, Elmer G, Kafkafi N, Golani I: Controlling the false discovery rate in behavior genetics research. Behav Brain Res 2001, 125:279-284.

38. Wu MC, Kraft P, Epstein MP, Taylor DM, Chanock SJ, Hunter DJ, Lin X: Powerful SNP-set analysis for case-control genome-wide association studies. Am J Hum Genet 2010, 86:929-942.

39. Wu MC, Lee S, Cai T, Li Y, Boehnke M, Lin X: Rare-variant association testing for sequencing data with the sequence kernel association test. Am J Hum Genet 2011, 89:82-93.

40. Lenci RE, Rachakonda PS, Kubarenko AV, Weber ANR, Brandt A, Gast A Sucker A, Hemminki K, Schadendorf D, Kumar R: Integrin genes and susceptibility to human melanoma. Mutagenesis 2012, 27:367-373.

41. Anz D, Mueller W, Golic M, Kunz WG, Rapp M, Koelzer VH, Ellermeier J, Ellwart JW, Schnurr M, Bourquin C, Endres S: CD103 is a hallmark of tumor-infiltrating regulatory T cells. Int J Cancer 2011, 129:2417-2426.

42. Venkataraman G, Aguhar C, Kreitman RJ, Yuan CM, Stetler-Stevenson M: Characteristic CD103 and CD123 expression pattern defines hairy cell leukemia: usefulness of CD123 and CD103 in the diagnosis of mature B-cell lymphoproliferative disorders. Am J Clin Pathol 2011, 136:625-630.

43. Tsilidis KK, Helzlsouer KJ, Smith MW, Grinberg V, Hoffman-Bolton J, Clipp SL, Visvanathan K, Platz EA: Association of common polymorphisms in IL10, and in other genes related to inflammatory response and obesity with colorectal cancer. Cancer Causes Control 2009, 20:1739-1751.

44. Ni J, Ye Y, Teng F, Wu Q: Interleukin 10 polymorphisms and cervical cancer risk: a meta-analysis. Int J Gynecol Cancer 2013, 23:126-133.

45. Xue H, Wang Y, Lin B, An J, Chen L, Chen J, Fang JY: A meta-analysis of interleukin-10-592 promoter polymorphism associated with gastric cancer risk. PLoS One 2012, 7:e39868.

46. Pan F, Tian J, Pan Y, Zhang Y: Association of IL-10-1082 promoter polymorphism with susceptibility to gastric cancer: evidence from 22 case-control studies. Mol Biol Rep 2012, 39:7143-7154.

47. Castro FA, Koshiol J, Hsing AW, Gao Y, Rashid A, Chu LW, et al: Inflammatory gene variants and the risk of biliary tract cancers and stones: a population-based study in China. BMC Cancer 2012, 12:468

doi:10.1186/2045-3329-3-12

Cite this article as: O'Brien et al:: Gastrointestinal stromal tumors: a caseonly analysis of single nucleotide polymorphisms and somatic mutations. Clinical Sarcoma Research 2013 3:12.

\section{Submit your next manuscript to BioMed Central and take full advantage of:}

- Convenient online submission

- Thorough peer review

- No space constraints or color figure charges

- Immediate publication on acceptance

- Inclusion in PubMed, CAS, Scopus and Google Scholar

- Research which is freely available for redistribution

Submit your manuscript at www.biomedcentral.com/submit
Ciomed Central 